\title{
Oncostatin M Is a Proinflammatory Mediator \\ In Vivo Effects Correlate with Endothelial Cell Expression of Inflammatory Cytokines and Adhesion Molecules
}

\author{
Vijayanand Modur, ${ }^{\star \ddagger}$ Michael J. Feldhaus, ${ }^{\star \ddagger}$ Andrew S. Weyrich, ${ }^{\star \S}$ Douglas L. Jicha,, Stephen M. Prescott, ${ }^{\$ \uparrow}$ \\ Guy A. Zimmerman, ${ }^{\star \S}$ and Thomas M. Mclntyre ${ }^{\star \star \S}$ \\ *Nora Eccles Harrison Cardiovascular Research and Training Institute, ${ }^{\ddagger}$ Department of Pathology, ${ }^{\S}$ Department of Internal Medicine, \\ "Division of Vascular Surgery, and "Program in Human Molecular Biology and Genetics, University of Utah School of Medicine, \\ Salt Lake City, Utah 84112
}

\begin{abstract}
Oncostatin M is a member of the IL-6 family of cytokines that is primarily known for its effects on cell growth. Endothelial cells have an abundance of receptors for oncostatin $\mathrm{M}$, and may be its primary target. We determined if oncostatin $M$ induces a key endothelial cell function, initiation of the inflammatory response. We found that subcutaneous injection of oncostatin $M$ in mice caused an acute inflammatory reaction. Oncostatin $\mathrm{M}$ in vitro stimulated: (a) polymorphonuclear leukocyte (PMN) transmigration through confluent monolayers of primary human endothelial cells; (b) biphasic PMN adhesion through rapid P-selectin expression, and delayed adhesion mediated by E-selectin synthesis; (c) intercellular adhesion molecule-1 and vascular cell adhesion molecule-1 accumulation; and (d) the expression of PMN activators IL-6, epithelial neutrophil activating peptide-78, growth-related cytokine $\alpha$ and growth-related cytokine $\beta$ without concomitant IL-8 synthesis. The nature of the response to oncostatin $M$ varied with concentration, suggesting high and low affinity oncostatin $M$ receptors independently stimulated specific responses. Immunohistochemistry showed that macrophage-like cells infiltrating human aortic aneurysms expressed oncostatin $M$, so it is present during a chronic inflammatory reaction. Therefore, oncostatin M, but not other IL-6 family members, fulfills Koch's postulates as an inflammatory mediator. Since its effects on endothelial cells differ significantly from established mediators like $\mathrm{TNF} \alpha$, it may uniquely contribute to the inflammatory cycle. (J. Clin. Invest. 1997. 100:158168.) Key words: neutrophils • E-selectin • P-selectin • IL-6 • IL-8
\end{abstract}

\section{Introduction}

Oncostatin $\mathrm{M}$ is a member of the IL-6 family of cytokines, which additionally includes leukemia inhibitory factor (LIF) ${ }^{1}$ IL-11, ciliary neurotrophic factor (CNTF), and cardiotrophin-1

Address correspondence to Thomas M. McIntyre, Ph.D., Nora Eccles Harrison CVRTI, Bldg. 500, University of Utah, Salt Lake City, UT 84112. Phone: 801-581-8183; FAX: 801-581-3128; E-mail: mcintyre@ cvrti.utah.edu

Received for publication 7 January 1997 and accepted in revised form 2 April 1997.

J. Clin. Invest.

(C) The American Society for Clinical Investigation, Inc. 0021-9738/97/07/0158/11 \$2.00

Volume 100, Number 1, July 1997, 158-168
(CT-1). Oncostatin M, like other family members, has high amino acid conservation, alignment of conserved residues, and conservation of genomic organization compared to IL-6 $(1,2)$. The conservation of structure extends to their receptors, and oncostatin M shares a subunit with the IL-6 receptor (gp130) and can use the LIFR $\beta$ subunit of the LIF receptor (3-5). Oncostatin $\mathrm{M}$ was originally isolated as a factor secreted from activated $\mathrm{T}$ cells that suppressed the growth of human melanoma cell lines but, intriguingly, failed to retard the growth of normal fibroblasts (6). However, subsequently it was found to stimulate the growth of other transformed and malignant cells, and to possess a variety of other functions $(7,8)$. In addition to its role in growth and differentiation, oncostatin $\mathrm{M}$ is immunomodulatory as it is synthesized by stimulated $\mathrm{T}$ cells and monocytes (6). Several lines of evidence indicate that endothelial cells may be primary targets of oncostatin M. First, endothelial cells are the richest source of receptors for oncostatin $\mathrm{M}$ yet to be identified. Endothelial cells have 4,000 high affinity receptors and 100,000 low affinity receptors (9). This is a 10- to 20-fold greater expression of these receptors compared to other cell types $(9,10)$, and is especially significant when compared to the estimated $650 \mathrm{TNF}$ receptors expressed by endothelial cells $(2,9)$. Second, endothelial cells respond to oncostatin M with activation of MAP kinase activity (11), IL-6 secretion (9), and delayed, but prolonged, P-selectin synthesis (12). Third, oncostatin $\mathrm{M}$ is the major autocrine growth factor for Kaposi's sarcoma cells (13), and these spindle-shaped cells are thought to be of endothelial cell origin $(14,15)$.

The physiologic or pathologic roles of oncostatin $M$ have not yet been established. Transgenic expression of oncostatin $\mathrm{M}$ under the control of nonspecific promoters is lethal (16), but expression using cell-specific promoters in lymphocytes of the early $\mathrm{T}$ cell lineage caused extrathymic expansion and maturation that may be therapeutic for $\mathrm{T}$ cell immunodeficiencies (17). Ectopic expression under the control of the insulin promoter, in contrast, produced mice whose pancreas showed fibrosis and lymphocytic cuffing around pancreatic islets and blood vessels (16). These changes are signs of a chronic inflammatory reaction, but IL-6 family members are generally not considered to be proinflammatory $(1,8)$. Instead, their role, exemplified by induction of the acute phase response, is considered to be reparative or even, as proposed for oncostatin $\mathrm{M}$ (18), antiinflammatory. Despite this generalization, recent data suggest that oncostatin $\mathrm{M}$ could be directly proinflammatory. Oncostatin $\mathrm{M}$ increases $\mathrm{P}$-selectin synthesis in primary

1. Abbreviations used in this paper: ENA-78, epithelial neutrophil activating peptide-78; GRO, growth related cytokine; ICAM-1, intercellular adhesion molecule-1; LIF, leukemia inhibitory factor; VCAM-1, vascular cell adhesion molecule-1. 
cultures of endothelial cells over a several day period, and this increases leukocyte adhesion (12). Additionally, oncostatin M is present during the inflammatory cycle of response and repair as there is a 100-fold increase in circulating levels in septic patients (19).

We explored the potential of oncostatin $\mathrm{M}$ as an inflammatory effector, and found mutually supporting lines of evidence showing that it could contribute to homeostasis in this way. We found that oncostatin $\mathrm{M}$ caused an acute inflammatory reaction in vivo, and that it colocalized with TNF-secreting cells in chronically inflamed human vascular tissue. It induced transmigration of human neutrophils through monolayers of endothelial cells by stimulating the expression of adhesion molecules and chemokines. The pattern of endothelial cell responses, however, significantly differed from the response to TNF. Additionally, the nature of the response depended on the concentration of oncostatin $\mathrm{M}$ as low and high affinity receptors individually stimulated proinflammatory events. We show that oncostatin $\mathrm{M}$ is a unique member of the IL- 6 family that is a direct inflammatory mediator.

\section{Methods}

Reagents. Recombinant human TNF was generously provided by Genentech Inc. (South San Francisco, CA). Recombinant human oncostatin M, IL-6, IL-8, LIF, IL-11, epithelial neutrophil activating peptide-78 (ENA-78), CNTF, anti-E-selectin antibody (BBA 8), and polyclonal anti-human antibodies to oncostatin M, TNF, and ENA78 were from R \& D Systems, Inc. (Minneapolis, MN). HBSS and M199 were obtained from Whittaker M.A. Bioproducts, Inc. (Walkersville, MD) and HSA was from Miles Laboratories, Inc. (Elkhart, IN). Mouse anti-human E-selectin antibody (3E6) and anti-human P-selectin antibody (G1) were gifts from Dr. Rodger McEver (University of Oklahoma). Anti-intercellular adhesion molecule-1 (ICAM-1) (18E3D) was a gift from Michael Gallatin and Pat Hoffman (ICOS Corp., Bothell, WA). Endogen, Inc. (Woburn, MA) supplied polyclonal rabbit antihuman IL-6. Mouse monoclonal antivascular cell adhesion molecule-1 (VCAM-1) was obtained from Biodesign International (Kennebunkport, ME). ECL Western blotting reagents were purchased from Amersham Corp. (Arlington Heights, IL). All secondary antibodies were obtained from Biosource International (Camarillo, CA). Other reagents were from Sigma Chemical Co. (St. Louis, MO).

In situ localization of oncostatin $M$. Specimens of aortic aneurysm were obtained at the time of surgery and specimens of normal aortas were obtained postmortem. Protocols to obtain surgical and cadaveric tissue samples were approved by the University of Utah's Institutional Review Board. Each specimen was fixed in Histochoice MB (Amresco Inc., Solon, $\mathrm{OH}$ ) before embedding in paraffin and sectioning into $4 \mu \mathrm{m}$ slices. The slices were deparaffinized with a graded ethanol series, hydrated, endogenous peroxidase quenched with $0.3 \% \mathrm{H}_{2} \mathrm{O}_{2}$, and stained with goat anti-oncostatin $\mathrm{M}$ and antiTNF antibodies at $1 \mu \mathrm{g} / \mathrm{ml}$ in PBS with $1 \%$ rabbit serum overnight. The antibodies were detected by an anti-goat vectastain kit according to manufacturer's instructions (Vector Laboratories, Inc., Burlingame, CA). Positive staining developed as a brown reaction precipitate. The sections were photographed under light microscopy by Nomarski interference optics. Sections stained with goat IgG or with secondary antibody alone showed insignificant amounts of brown reaction product.

In vivo inflammatory responses to oncostatin $M$. On the day of the experiment, hair on the backs of female Swiss 44, 6-8-wk-old mice was removed and $1 \mu \mathrm{g}$ (45 picomols) of oncostatin M in $10 \mu \mathrm{l}$ PBS with $1 \%$ HSA, or PBS with $1 \%$ HSA alone was injected subcutaneously with a 32-gauge needle. The mice were killed by cervical dislocation at the desired time points, the site of injection was ex- cised, and was fixed in $10 \%$ formalin overnight. The excised tissue was embedded in paraffin, sectioned, and stained with eosin and hematoxylin to examine inflammatory infiltrates.

Cell manipulations. Human umbilical vein endothelial cells (HUVEC) were cultured in 24-mm multiwell plates or 24-mm transwell membranes (Costar Data Packaging Corp., Cambridge, MA) as described (20). Only monolayers of primary cultures that were tightly confluent ( $24 \mathrm{~h}$ postconfluence) were used for these studies. Neutrophils were isolated from human blood and labeled with ${ }^{111}$ In-oxine as before (20). Endothelial cell and blood procurement was approved by the University of Utah's Institutional Review Board. Endothelial cells were treated with the stated agonist in HBSS containing $0.5 \%$ HSA (HBSS/A) for the specified period of time before adhesion of ${ }^{111}$ In-PMN to activated endothelial cells was quantified as described (21). When the effect of anti-E-selectin or anti-P-selectin antibody on PMN-endothelial cell interactions was examined, the monolayer was preincubated for $15 \mathrm{~min}$ with $10 \mu \mathrm{g} / \mathrm{ml}$ of blocking P6E2 mAb or $10 \mu \mathrm{g} / \mathrm{ml}$ of blocking anti-P-selectin $\mathrm{G} 1 \mathrm{mAb}$. The adhesion assay was performed in the presence of this concentration of antibody. A positive control for antibody effectiveness was included in each experiment. Neutrophil transmigration over a $60 \mathrm{~min}$ period was determined in triplicate by adding $250 \mu \mathrm{l}$ of ${ }^{111}$ In-labeled PMN $\left(2.0 \times 10^{6}\right.$ cells per $\mathrm{ml}$ ) over agonist-treated HUVEC that had been grown on transwell inserts. The assay wells were chilled on ice, and PMN that migrated through the monolayer were collected and counted. Transmigration is reported as the mean and SEM of triplicate values. Flow cytometry of endothelial cells was performed as described (22).

Biochemical and molecular biologic protocols. Cytokines and chemokines were quantitated in endothelial cell supernatants by sandwich ELISA with polyclonal anti-human antibody; detection employed biotinylated rabbit anti-human IL-8, ENA-78 or IL-6, and avidin-conjugated horseradish peroxidase (23). Material for Western blots was collected by solubilizing monolayers with boiling Laemmli sample buffer (24) without $\beta$-mercaptoethanol. E-selectin was immunoblotted as described earlier (23). Reverse transcription and PCR was performed as described (25). Specifically, IL-6 PCR was performed using sense primer 5'-ATG AAC TCC TTC TCC ACA AGC-3' spanning the nucleotides $51-71$ and antisense primer $5^{\prime}$-TTC TCG GGA GTC CGA CCT GAC-3' spanning nucleotides 657-677 of the IL-6 cDNA sequence. ENA-78 PCR was performed using sense primer 5'-GCC CGT GTC CCC GGT CCT TCG AG-3' spanning the nucleotides 121-152 and antisense primer 5'-CTG GAT CAA GAC AAA TTT CCT TC-3' spanning nucleotides $602-625$ of the ENA-78 genomic sequence. The product of the reactions for IL-6 and ENA-78 were 659 and $257 \mathrm{bp}$, respectively. PCR for growth related cytokine (GRO) $\alpha$ and GRO $\beta$ was performed as described (26).

\section{Results}

Localization of oncostatin $M$ in human aortic aneurysms. We first determined whether or not oncostatin $\mathrm{M}$ was localized at sites of inflammation. For this we chose a chronically inflamed human tissue: abdominal aortic aneurysm tissue from surgical resections. Here, in addition to abnormal vascular dilation resulting from atherosclerotic weakening of the vessel wall, there is infiltration of macrophages and lymphocytes. This occurs in the intima, and in atherosclerotic lesions, in the adventitia. In the latter area there is also perivascular cuffing $(27,28)$ where the infiltrating leukocytes chronically secrete IL-1 and $\mathrm{TNF}$, denoting an ongoing inflammatory process $(28,29)$. We examined tissue sections from abdominal aortic aneurysms and found clusters of infiltrating mononuclear cells. Immunostaining of these sections for oncostatin $\mathrm{M}$ showed prominent staining of numerous macrophage-like cells (Fig. 1, top left). Smaller mononuclear cells with indistinct cytoplasm suggestive of lymphocytes failed to stain for oncostatin M. Immu- 


\section{Anti-oncostatin $\mathrm{M}$}
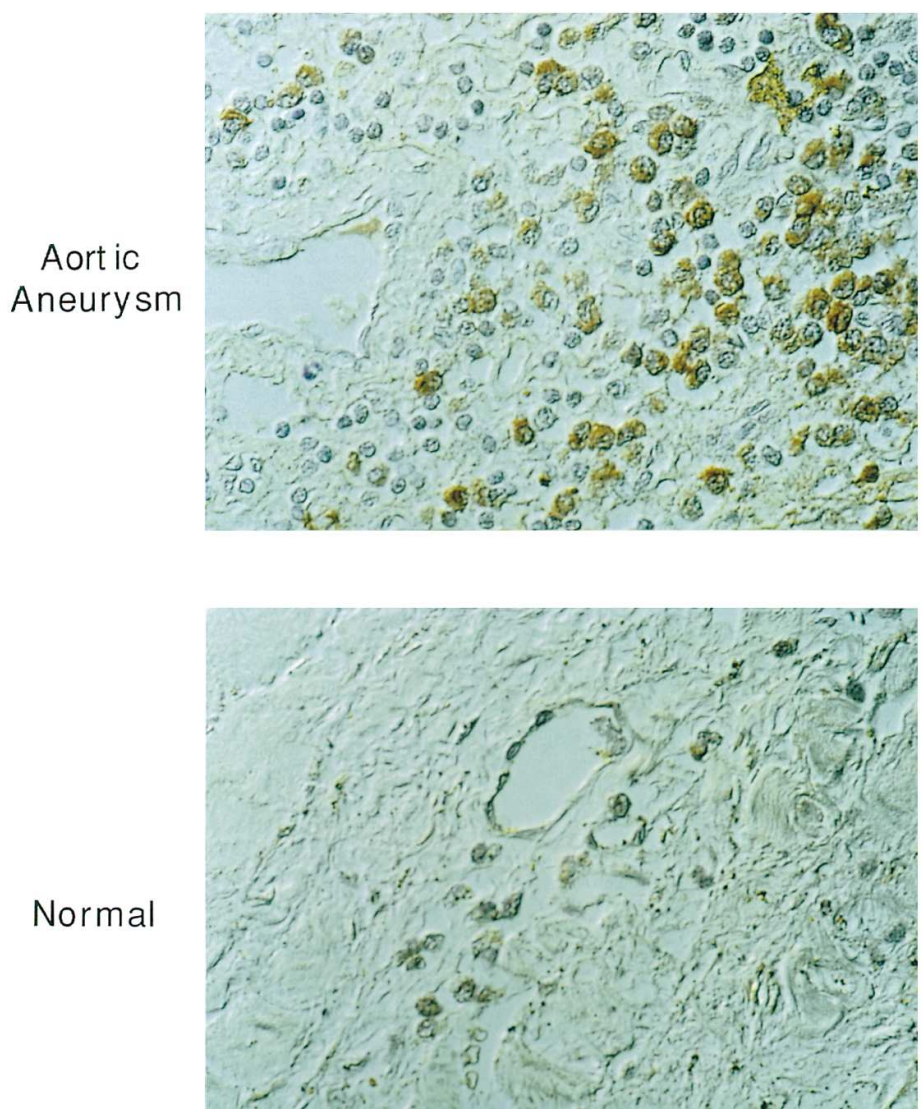

Anti-TNF
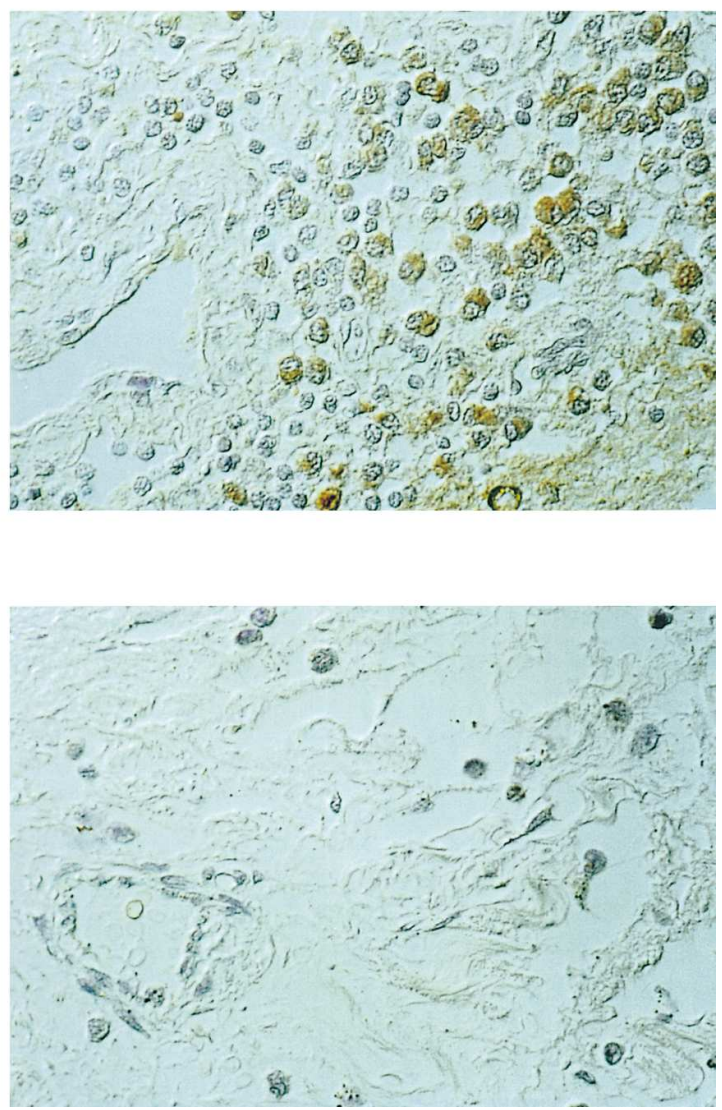

Figure 1. Oncostatin M is present in inflamed human aorta. Sections of aneurysmal (top) or normal (bottom) aorta were stained with goat polyclonal anti-oncostatin M (left) or goat polyclonal anti-TNF (right), detected with peroxidase conjugated anti-goat antibodies, and developed with diaminobenzidine. Positive staining indicated as a brown reaction precipitate. Sections were examined at $\times 40$ using Nomarski interference optics. We found that 8 of 12 specimens of aortic aneurysms stained positively for TNF and oncostatin M, while the remaining four aneurysms contained neither TNF nor oncostatin M.

nostaining of serial sections for TNF demonstrated an identical result. TNF was present in numerous large macrophage-like cells and absent in the smaller mononuclear cells (Fig. 1, top right). Sections of aortas from cadavers with unrelated disease showed rare mononuclear cells resembling leukocytes. We could not detect significant TNF in these cells even when we found several leukocytes in one area, although there may be a low level of oncostatin M staining in this infiltrate (Fig. 1, bottom, left and right). Thus, oncostatin $\mathrm{M}$ is present in a chronic human inflammatory lesion, and it colocalizes with another powerful proinflammatory cytokine, TNF.

In vivo inflammatory responses to oncostatin $M$. Our next goal was to determine if oncostatin $\mathrm{M}$ was sufficient to induce an inflammatory response. We injected $1 \mu \mathrm{g}$ (45 picomols) of recombinant human oncostatin $\mathrm{M}$ subcutaneously into mice, and examined the sites 6,12 , and $24 \mathrm{~h}$ after injection. Gross examination showed redness and swelling-classic signs of inflammation-at the site of oncostatin $\mathrm{M}$ injection at 6 and $12 \mathrm{~h}$, with subsidence at $24 \mathrm{~h}$. Microscopic examination of the fixed and stained sections from PBS injected controls (Fig. $2 A$ ) showed a normal venule with unremarkable histology, while the histopathology of sections derived from oncostatin M-injected dermis obtained at $6 \mathrm{~h}$ (Fig. $2 \mathrm{~B}$ ) and $12 \mathrm{~h}$ (not shown) postinjection showed tissue edema, capillary dilatation, and extravasation of leukocytes with disruption of normal histology. Higher magnification of another section obtained $6 \mathrm{~h}$ after oncostatin $\mathrm{M}$ injection revealed endothelial cell swelling and venules engorged with infiltrating inflammatory cells, many with the lobulated nucleus characteristic of polymorphonuclear cells (Fig. $2 \mathrm{C}$ ). These hallmarks of inflammation found in duplicate areas from each of three mice suggest that oncostatin $\mathrm{M}$ induces acute, but transient, inflammation.

Oncostatin $M$ induces PMN transmigration ex vivo. We determined whether or not oncostatin $\mathrm{M}$ acted on endothelial cells to induce leukocyte transmigration through tightly adjoined cells by growing primary human endothelial cells to confluence on a porous membrane. These were then exposed, or not, to oncostatin $\mathrm{M}$ for $4 \mathrm{~h}$ before the medium was removed and freshly isolated human PMN were added to the upper chamber of the transwell. After $1 \mathrm{~h}$ the quantity of PMN that had migrated to the lower chamber was determined. There was little migration of freshly isolated human neutrophils (PMN) through these monolayers in the absence of added agonists (Fig. 3), while addition of TNF, as expected, induced migration of PMN. After validating this transmigration assay, we examined oncostatin $\mathrm{M}$ and found that it caused a 10-fold in- 


\section{Treat ment}

A
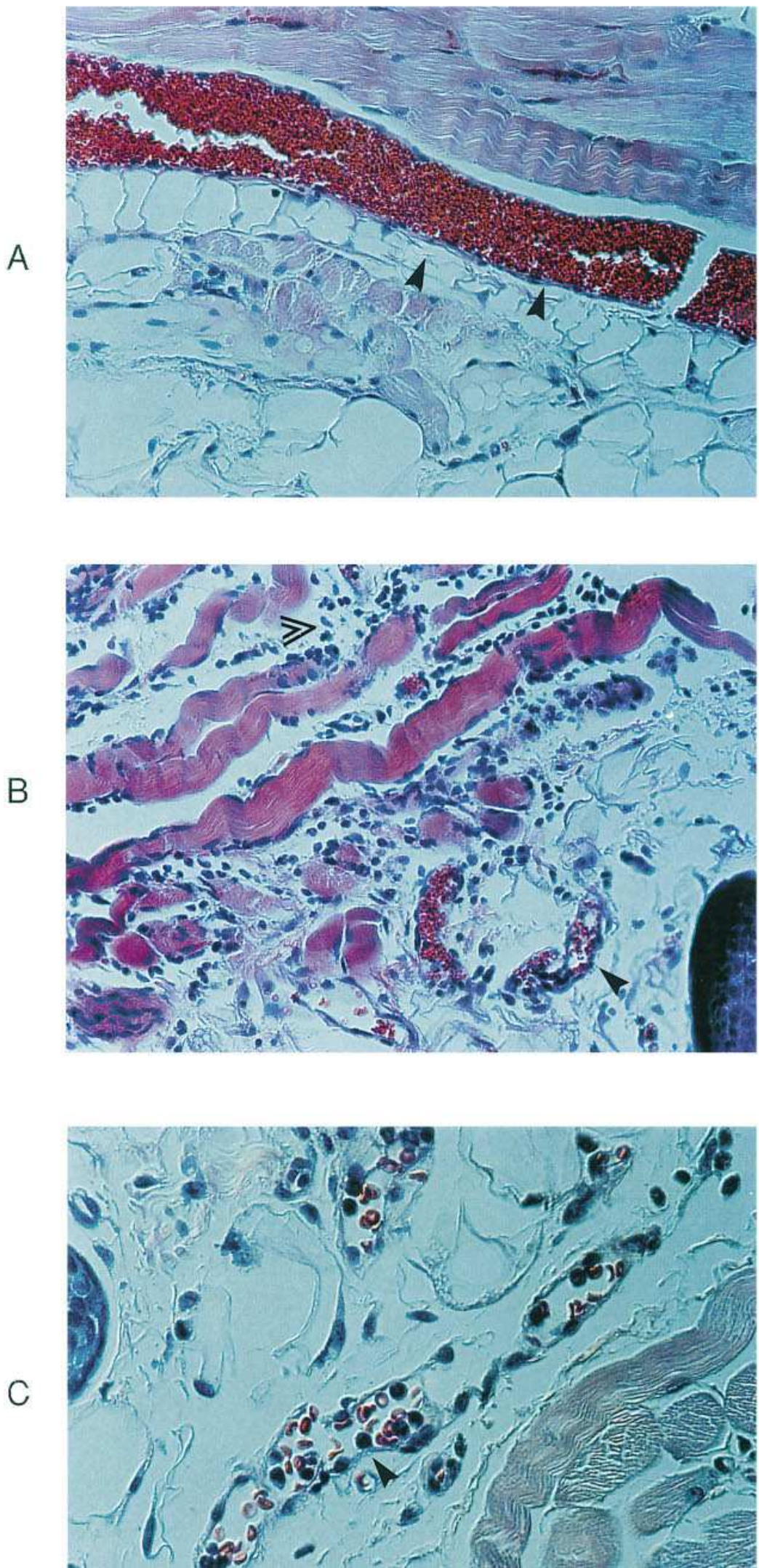

\section{Vehicle} $20 \mathrm{X}$

\section{Oncostatin M} $20 \mathrm{X}$

Figure 2. Oncostatin M induces an inflammatory response in vivo. $(A) \mathrm{Ve}$ hicle or $(B$ and $C)$ oncostatin $\mathrm{M}(1 \mu \mathrm{g})$ in vehicle was injected subcutaneously into mice. The mice were killed after $6 \mathrm{~h}$ and the tissue was prepared and stained with hematoxylin and eosin as described in Methods. Sections were examined by

Oncostatin M light microscopy at $20 \times$ ( $A$ and $B$ ) and $40 \times(C)$. Filled arrowheads, venules; open arrow heads, leukocytes. The images shown are from one of three experiments with similar results. 


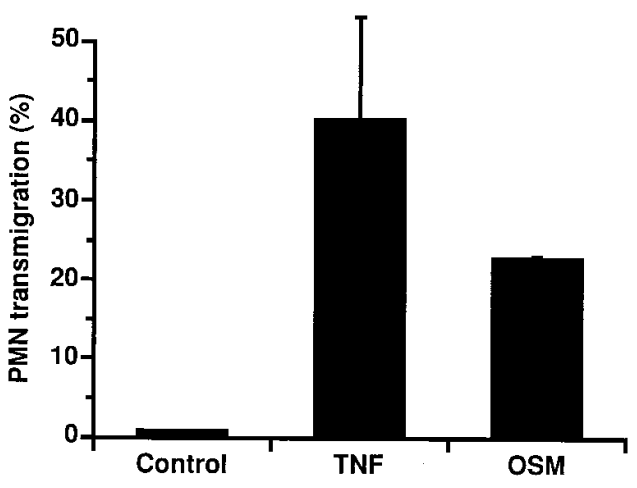

Figure 3. Oncostatin M treatment of endothelial cells induces PMN transmigration. Endothelial cells were incubated with $45 \mathrm{nM}$ oncostatin $\mathrm{M}$ or $1,000 \mathrm{U} / \mathrm{ml} \mathrm{TNF}$ for $4 \mathrm{~h}$ and PMN transmigration in $1 \mathrm{~h}$ was determined with ${ }^{111} \mathrm{In}-\mathrm{PMN}$ as described in Methods. The data shown are the mean \pm SEM of triplicate determinations from one experiment that is representative of three others.

crease in PMN migration through the monolayer. This indicates that oncostatin $\mathrm{M}$ activated isolated endothelial cells to display adhesion molecules necessary to bind PMN, and that it stimulated them to synthesize PMN agonists necessary for chemotaxis.

Oncostatin $M$ alone amongst its family members induces endothelial cell-dependent PMN adhesion. Next, we determined whether oncostatin M activated endothelial cells to bind PMN, or if it directly acted on PMN to stimulate chemotaxis. We found that treatment of PMN with $45 \mathrm{nM}$ oncostatin $\mathrm{M}$ failed to activate $\beta_{2}$-dependent adhesion (not shown), suggesting that the effect of oncostatin $\mathrm{M}$ was on the endothelial cells. We examined this by exposing monolayers grown on a solid surface to individual cytokines for $4 \mathrm{~h}$ before adding unactivated PMN. We found that PMN would adhere to monolayers stimulated with oncostatin $\mathrm{M}$, as they did to monolayers stimulated with the endothelial cell agonist TNF (Fig. 4). We also found that none of the other members of the IL- 6 family of cytokines could stimulate this endothelial cell-dependent adhesion. Consistent with this, when we extracted proteins from these monolayers to look for E-selectin expression, or assayed the supernatants from these incubations for stimulation of IL-8 and IL-6 secretion, we found no expression of any of these proteins by these family members (data not shown). We examined CNTF separately, and found this family member also was unable to stimulate endothelial cells to bind PMN (not shown). Therefore oncostatin $\mathrm{M}$ altered endothelial cell function; it was the only member of its family to do so.

Oncostatin $M$ induces a biphasic response in endothelial cells. We exposed endothelial cells to oncostatin M for varying periods of time and found that PMN appeared to adhere to endothelial cells in two distinct phases (Fig. 5). Initially there was a near doubling of adherent PMN that was maximal by 30 min. This was followed by a more slowly developing, but more pronounced, increase in adhesivity that was maximal between 4 and $6 \mathrm{~h}$. These phases were not clearly separable as there was no intervening time when adhesion returned to basal levels. Neither the early nor the later peak of PMN adhesion was a result of endotoxin contamination, a potent and pervasive endothelial cell agonist. Polymyxin B, at concentrations able to block

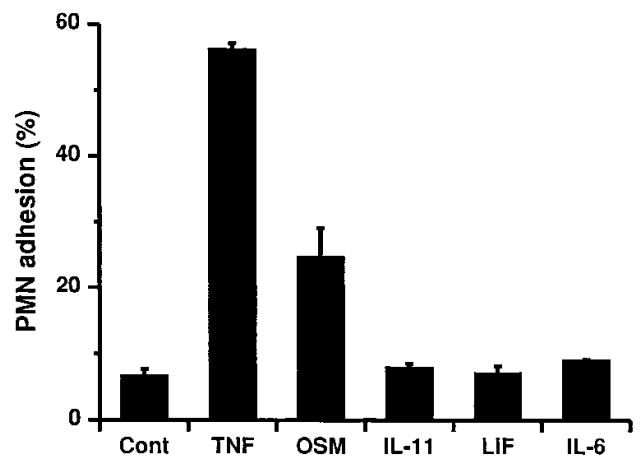

Figure 4. Oncostatin M, but not its family members, induces PMN adhesion to endothelial cells. Endothelial cells were incubated with $45 \mathrm{nM}$ IL-6, IL-11, LIF, oncostatin M, or 1,000 U/ml TNF for $4 \mathrm{~h}$. Then ${ }^{111}$ In-PMN adhesion to the monolayer during a 5 -min period was quantitated as a percent of total PMN added. The values shown are mean \pm SEM of duplicate determinations and results are representative of three experiments.

increased adhesivity caused by LPS, did not inhibit adhesion, and boiling the oncostatin $\mathrm{M}$ destroyed these responses (not shown). Additionally, an anti-gp130 monoclonal antibody, which blocks all IL-6 type receptors, inhibited endothelial cell responsiveness to oncostatin $\mathrm{M}$ (vide infra).

High and low affinity oncostatin $M$ receptors separately induce P-selectin- and E-selectin-dependent PMN adhesion. We characterized the concentration response of the early adhesive event to oncostatin $\mathrm{M}$, and found that endothelial cells were quite sensitive to the cytokine (Fig. $6 A$ ). Adhesion after 15 min of exposure to oncostatin $\mathrm{M}$ was detected at $45 \mathrm{pM}$, and became maximal by $450 \mathrm{pM}$. Higher concentrations of oncostatin $\mathrm{M}$ somewhat dampened this response, which may reflect a function of the low affinity oncostatin $M$ receptor (see below). Since rapid changes in endothelial cell adhesivity in response to other cytokines or pharmacologic agents is mediated by preformed $\mathrm{P}$-selectin translocation from intracellular stores, we determined what effect a blocking monoclonal antibody had on oncostatin M-induced adhesion. We found that the inhibitory G1 (Fig. $6 \mathrm{~B}$ ), but not the nonblocking S12 antibody (not shown) (30), completely blocked the PMN adhesion induced by a short exposure to oncostatin $\mathrm{M}$, so oncostatin $\mathrm{M}$

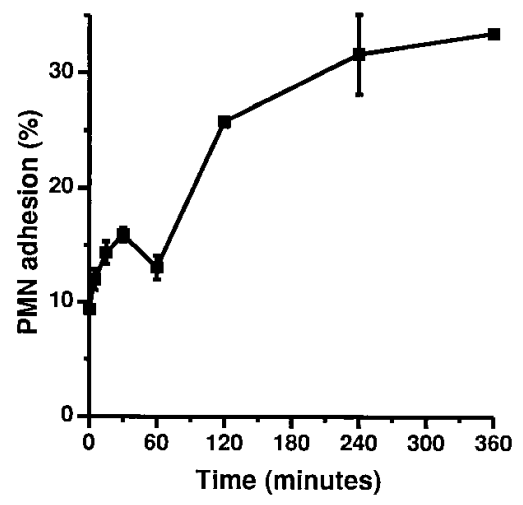

Figure 5. Oncostatin M induces biphasic timedependent PMN adhesion to endothelial cells. Endothelial cells were incubated with $45 \mathrm{nM}$ of oncostatin $\mathrm{M}$ for the stated times, the oncostatin M was removed, and PMN adhesion was determined as in Fig. 4. The data shown is the mean \pm SEM of duplicate determinations from one experiment that is representative of three. 


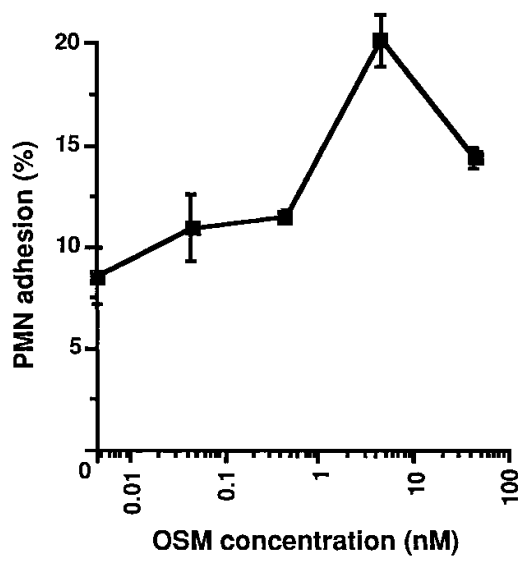

B

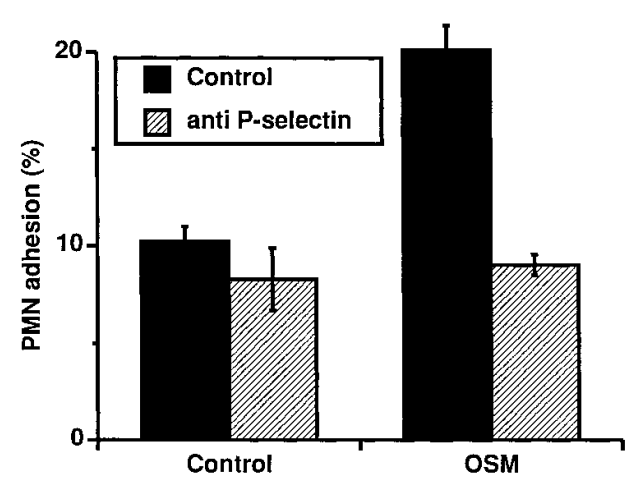

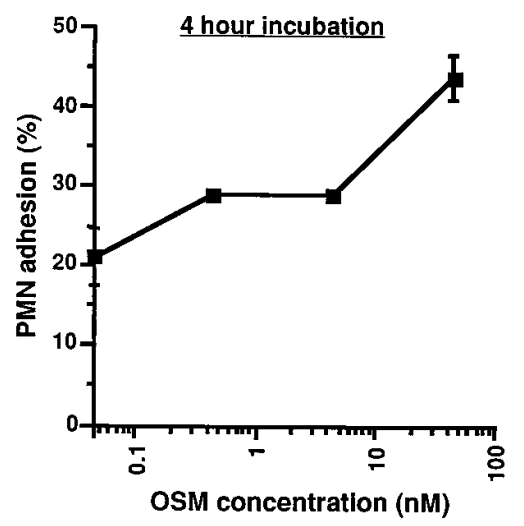

D

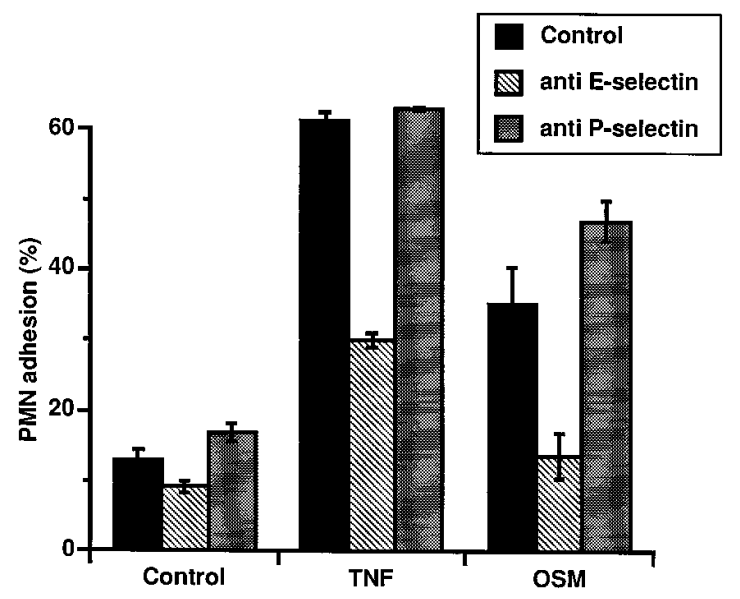

Figure 6. Oncostatin M activates endothelial cells to bind PMN via P- and E-selectin at two distinct times. $(A)$ Endothelial cells were incubated with the stated concentrations of oncostatin $\mathrm{M}$ for $15 \mathrm{~min}$ or $(B)$ endothelial cells were incubated with buffer or $0.45 \mathrm{nM}$ oncostatin $\mathrm{M}$ for $15 \mathrm{~min}$, in the presence or absence of $10 \mu \mathrm{g} / \mathrm{ml}$ blocking anti P-selectin antibody and ${ }^{111} \mathrm{In}$-PMN adhesion was determined as before. (C) Endothelial cells were incubated with the stated concentrations of oncostatin $\mathrm{M}$ for $4 \mathrm{~h}$ and ${ }^{111} \mathrm{In}$-PMN adhesion was determined as before. $(D)$ Endothelial cells were incubated with buffer or $45 \mathrm{nM}$ oncostatin $\mathrm{M}$ for $4 \mathrm{~h}$, and then anti E-selectin or anti P-selectin antibody was added to a final concentration of $10 \mu \mathrm{g} / \mathrm{ml}$. The cells were incubated with these antibodies for a further $15 \mathrm{~min}$ at $37^{\circ} \mathrm{C}$ before ${ }^{111} \mathrm{In}$-PMN adhesion was determined. The data shown are the mean \pm SEM of duplicate determinations from one experiment that is representative of four $(A$ and $C)$ and two experiments $(B$ and $D)$.

behaves like other rapidly-acting agonists. Next, we examined the increase in endothelial cell adhesivity produced by exposure to oncostatin $\mathrm{M}$ for several hours. Here we found little adhesion at low concentrations of oncostatin M (Fig. $6 C$ ) where the rapid response occurred, with a progressive increase in adhesion as the concentration was increased from 0.45 to $45 \mathrm{nM}$. We found that the blocking P-selectin antibody did not inhibit PMN adhesion after $4 \mathrm{~h}$ of stimulation with oncostatin M (Fig. $6 \mathrm{D}$ ), but instead it was inhibited by an antibody that blocks E-selectin function. We confirmed that E-selectin was expressed on the surface of endothelial cells treated with $45 \mathrm{nM}$ oncostatin M by FACScan (not shown). Oncostatin M is therefore an unusual endothelial cell agonist that induces biphasic leukocyte adhesion through the rapid translocation of stored P-selectin to the cell surface and then through the delayed synthesis and surface expression of E-selectin.

Oncostatin $M$ induces endothelial cell expression of adhesion molecules. The inflamed proadhesive state of endothelial cells generally results from the coordinated expression of sev- eral surface cell adhesion molecules (31). We determined if multiple adhesion proteins are induced by oncostatin $\mathrm{M}$ by examining the de novo synthesis of E-selectin by immunoblotting, and quantified surface expression of ICAM-1 and VCAM-1 by flow cytometry. As anticipated from experiments with blocking E-selectin antibodies, oncostatin $\mathrm{M}$ induced E-selectin synthesis after $4 \mathrm{~h}$ of exposure (Fig. $7 \mathrm{~A}$ ). This induction was apparent only at the higher concentrations of oncostatin $\mathrm{M}$, and so paralleled the second phase of stimulated PMN adhesion. ICAM-1 expression was enhanced several-fold over basal levels by $45 \mathrm{nM}$ oncostatin $\mathrm{M}$, as it was by TNF (Fig. 7 $B)$. Oncostatin $\mathrm{M}$ also induced a modest induction of surface VCAM-1 expression (Fig. $7 \mathrm{C}$ ), which could reliably be detected only at $45 \mathrm{nM}$ oncostatin $\mathrm{M}$ (data not shown). Thus oncostatin M, likely through a low affinity receptor, induces a coordinated surface expression of adhesion molecules that mediate interactions with a variety of leukocyte subtypes.

Oncostatin $M$ induces $C$ - $X$ - $C$ chemokine synthesis. Leukocytes adherent to stimulated endothelial cells become acti- 
A

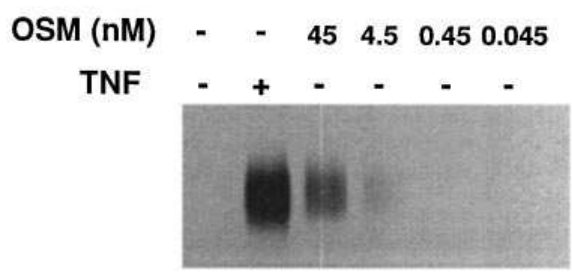

B

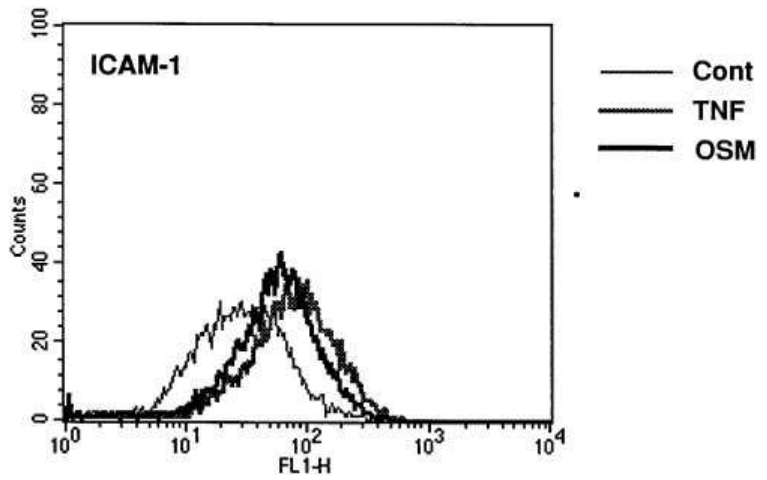

C

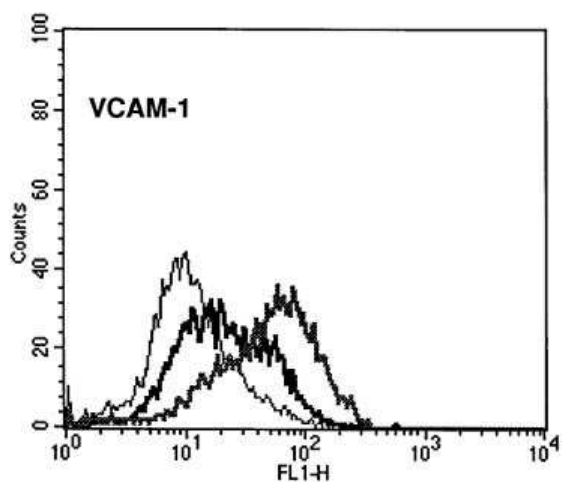

Figure 7. Oncostatin M differentially activates endothelial cell inflammatory responses. Endothelial cell monolayers were treated with buffer, 1,000 U/ml TNF, or $45 \mathrm{nM}$ oncostatin M for $4 \mathrm{~h}$. (A) Cell lysates were then assayed for E-selectin protein expression by immunoblotting with mAb BBA-8. (B) Detached cells were then stained for ICAM-1 with mAb 18E3D. (C) Detached cells were stained for VCAM-1 with mAb 1G11. Expression of ICAM-1 and VCAM-1 was analyzed by flow cytometry using nonimmune mouse IgG to determine nonspecific staining. The data presented are from one of three experiments with similar results.

vated by endothelial cell-derived agonists (32). For TNF $\alpha-$ activated endothelial cells, the signaling molecule is IL-8 (33), a member of the C-X-C chemokine family. We looked for its production, but found that oncostatin $\mathrm{M}$ did not stimulate IL-8 secretion (Fig. $8 \mathrm{~A}$ ). Earlier we found that endothelial cells produce ENA-78, another C-X-C chemokine (34), so we determined whether oncostatin $\mathrm{M}$-stimulated endothelial cells produced this chemokine. We found that oncostatin $\mathrm{M}$ enhanced ENA-78 synthesis and secretion, while TNF did not (Fig. $8 \mathrm{~A}$ ). We determined whether other members of this chemokine family were responsive to oncostatin $\mathrm{M}$ by estimat- ing their mRNA levels by PCR. We found, as anticipated from changes in protein secretion, that endothelial cells exposed to oncostatin $M$ expressed message for ENA-78, but not IL-8 (Fig. $8 \mathrm{~B}$ ). Oncostatin $\mathrm{M}$ at $45 \mathrm{nM}$ additionally induced message for the chemokines GRO $\alpha$ and $\beta$. TNF, in contrast, was a poor agonist for both of these chemokines. We also found that GRO $\beta$ message, like that for IL-6, was maximally induced by 100 -fold lower levels of oncostatin M. Therefore synthesis of these two cytokines proceeds from the high affinity receptor, while $\mathrm{GRO} \alpha$ requires higher concentrations for induction. Since all the C-X-C chemokines induced by oncostatin M activate neutrophils, one or more of these can replace IL-8 as a leukocyte signaling molecule derived from activated endothelial cells.

Oncostatin M activates endothelial cells via gp130. Endothelial cells have low and high affinity receptors for oncostatin $\mathrm{M}$ (9) that could account for the different responses we found at high and low concentrations of oncostatin M. Both classes of receptors contain a common gp130 subunit so blocking antigp130 antibodies could inhibit all responses to oncostatin M. We first determined, by flow cytometry, that endothelial cells constitutively express gp130 (data not shown). We then exposed endothelial cells to this antibody before the addition of oncostatin M. We found that this prevented E-selectin expression by high concentrations of oncostatin M, but not TNF (Fig. $9 A$ ), and it prevented PMN adhesion to these cells (Fig. $9 B$ ). We also found this antibody blocked IL-6 secretion in response to low concentrations of oncostatin M (Fig. 9C). These results show that functional changes in endothelial cells in response to either low or high oncostatin M concentrations proceed through receptors that contain gp130, a component common to the currently known oncostatin $\mathrm{M}$ receptors.

\section{Discussion}

Our observation that oncostatin $\mathrm{M}$ induces an inflammatory response in vivo and in vitro is new, but the novel aspect of these results is that oncostatin $\mathrm{M}$ does not mimic other inflammatory mediators. For instance, oncostatin $M$ caused increased leukocyte adhesion within minutes, but this continued to increase over a period of several hours. Other agonists are monophasic. A second distinction between oncostatin $\mathrm{M}$ and mediators like TNF, lipopolysaccharide, and IL-1 is that oncostatin $\mathrm{M}$ failed to induce the synthesis of IL-8, a key component of the intercellular interaction that activates PMN once they are bound to endothelial cells. Conversely, oncostatin $\mathrm{M}$ induced the synthesis of several other C-X-C chemokines that were not products of TNF-stimulated cells under these conditions. Finally, oncostatin $\mathrm{M}$ activation of endothelial cells differs from established mediators in that the nature of the proinflammatory response depends on the concentration of oncostatin M. These distinctions highlight the fundamental differences in signals originating from the TNF receptor and receptors containing gp130. This expands the repertoire of endothelial cell-signaling pathways that lead to an inflammatory phenotype, and it augments the group of cytokines that may participate in this process.

We found that oncostatin $\mathrm{M}$ induced a biphasic increase in PMN adhesion to endothelial cells. The first increase in adhesion derived from the high affinity receptor, and was mediated by P-selectin. Intracellular storage of P-selectin allows its rapid translocation to the plasma membrane, where it can then bind 
A

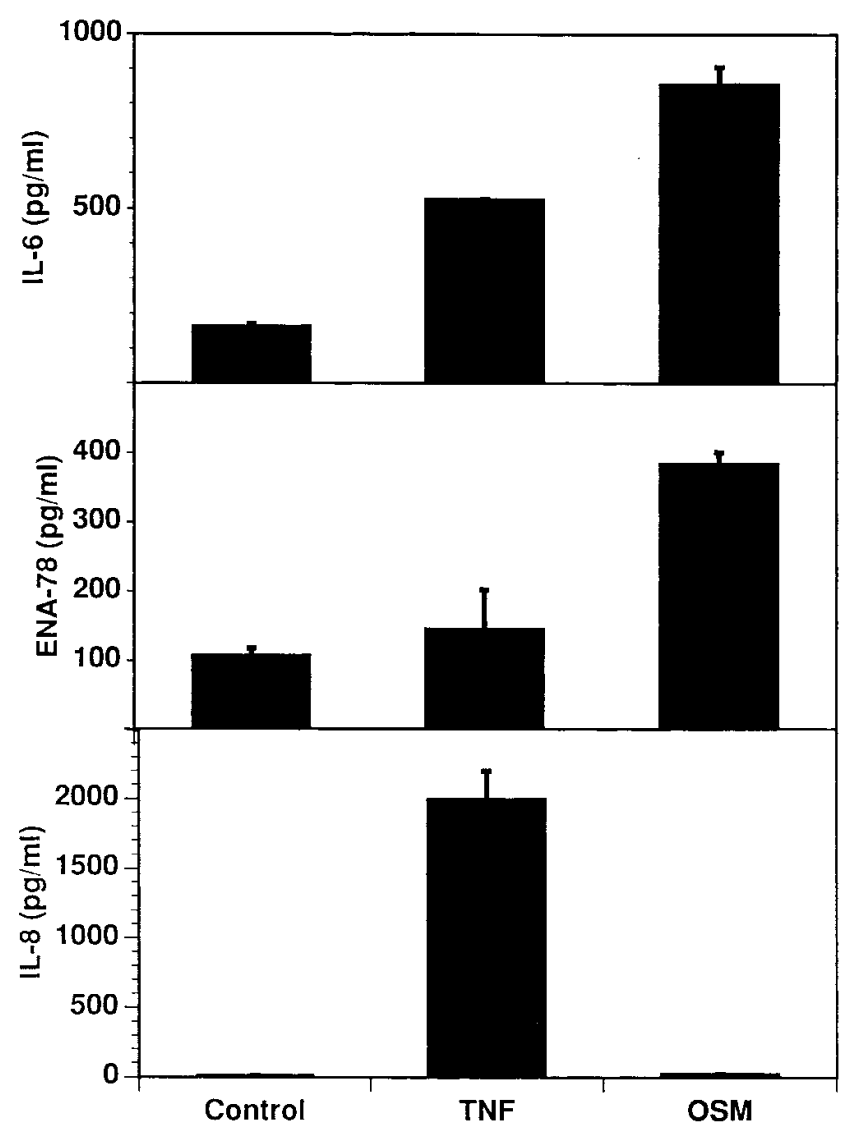

B

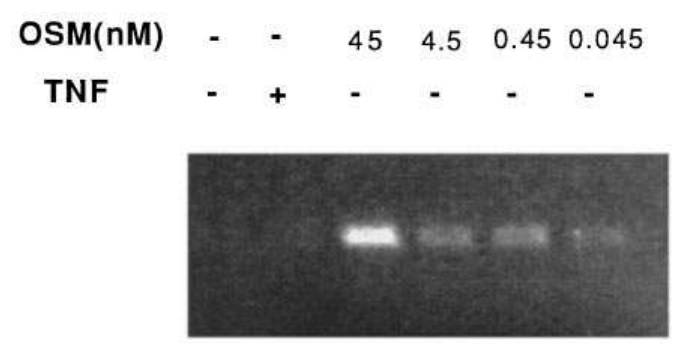

IL-6

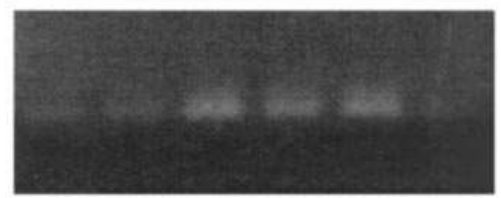

ENA-78

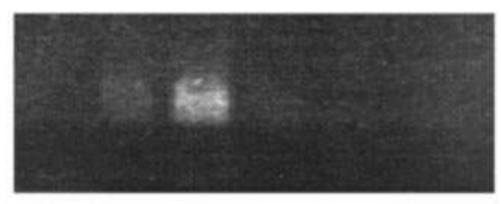

GRO $\alpha$

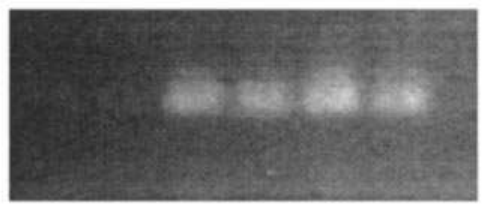

GRO $\beta$

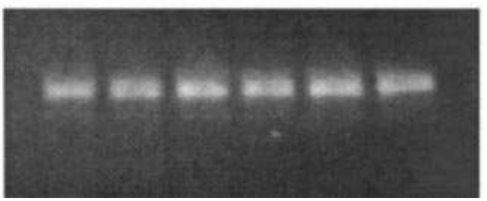

GAPDH

Figure 8. Oncostatin M induces cytokine and chemokine expression in endothelial cells. $(A)$ Endothelial cells were treated for $4 \mathrm{~h}$ with buffer alone, oncostatin M $(45 \mathrm{nM})$ or TNF (1,000 U/ml). Supernatants were collected and IL-6, IL-8, and ENA-78 concentrations were assayed by sandwich ELISA. $(B)$ Total RNA was extracted, and RT-PCR for IL-6, ENA-78, GRO $\alpha$, GRO $\beta$, and GAPDH was performed by using cytokine specific oligonucleotides described in Methods. The data are representative of four experiments $(A)$ and two experiments $(B)$.

the P-selectin glycoprotein ligand 1 (PSGL-1) constitutively expressed by PMN $(35,36)$. Oncostatin $M$ then stimulated a second phase of PMN adhesion through the low affinity receptor that depended on the stimulation of E-selectin transcription and expression. The level of PMN adhesion after oncostatin $M$ treatment was less than the TNF response, which correlated with a considerably smaller accumulation of E-selectin. A similar disparity exists between the amount of E-selectin and the level of PMN adhesion in endothelial cells treated with sphingomyelinase $(22,23)$ where the resulting increase in cellular ceramide allows modest levels of E-selectin to be disproportionally effective in binding PMN. We examined ceramide levels in oncostatin M-treated cells, but found that it did not stimulate this lipid mediator to accumulate (not shown). Oncostatin $M$ was quite effective in stimulating ICAM-1 synthesis which, as a counterligand for activated $\beta_{2}$-integrins on leukocytes, likely contributes to the adhesive interaction. Thrombin, which induces a small biphasic effect on leukocyte binding (37), induces a small amount of E-selectin expression in conjunction with a significant alteration in the avidity of endothelial cell ICAM-1 (38). It appears that secondary interactions may accompany and strengthen E-selectin-mediated leukocyte binding. Oncostatin $\mathrm{M}$ stimulation of leukocyte-endothelial cell interactions actually has a third phase where an increase in P-selectin transcription over a period of several days increases both basal and stimulated PMN adhesion (12). Our experiments did not reveal a P-selectin component to adhesion after $4 \mathrm{~h}$ of exposure because the induction of P-selectin transcription is slow (12) compared to E-selectin accumulation (Fig. 6 $D)$. Thus, oncostatin M stimulates leukocyte-endothelial cell interactions over an extraordinarily wide range of times.

The response to oncostatin $\mathrm{M}$ was a function not only of the time of exposure, but also of its concentration. In contrast, the response of endothelial cells to other inflammatory cytokines results from the activation of a single receptor that in turn induces a single, coordinated set of responses. The variable nature of the response to oncostatin $\mathrm{M}$ derives from the expression of two classes of receptors by endothelial cells (9). Binding studies suggest a high affinity receptor with an apparent $K_{\mathrm{d}}$ of $15 \mathrm{pM}$, and a low affinity receptor(s) with an apparent $K_{\mathrm{d}}$ of $1 \mathrm{nM}$. Our concentration response data suggest that the high affinity receptor induces IL-6 synthesis, as reported $(4,9)$; GRO $\beta$ expression; and, the rapid expression of P-selectin on the cell surface. The low affinity receptor on endothelial cells extends the proinflammatory response through the induction of E-selectin, ICAM-1, and VCAM-1 accumulation. The 
A

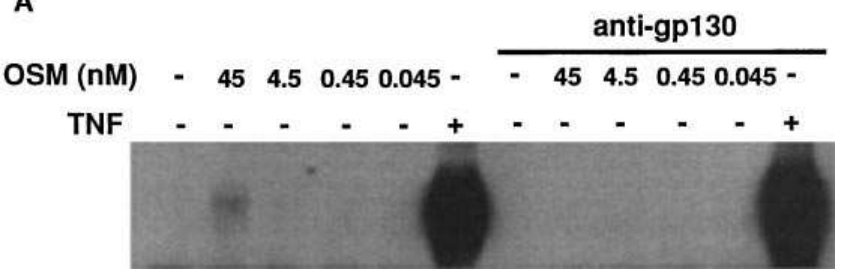

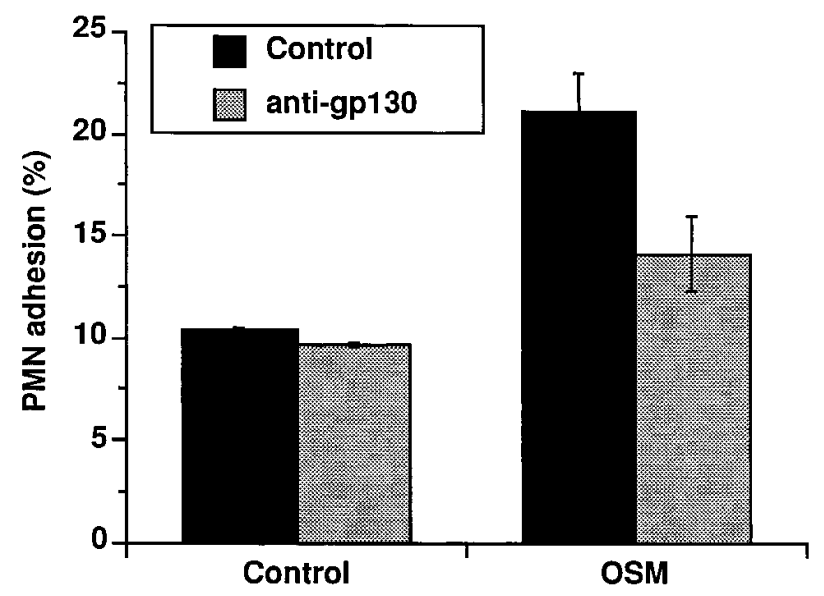

C

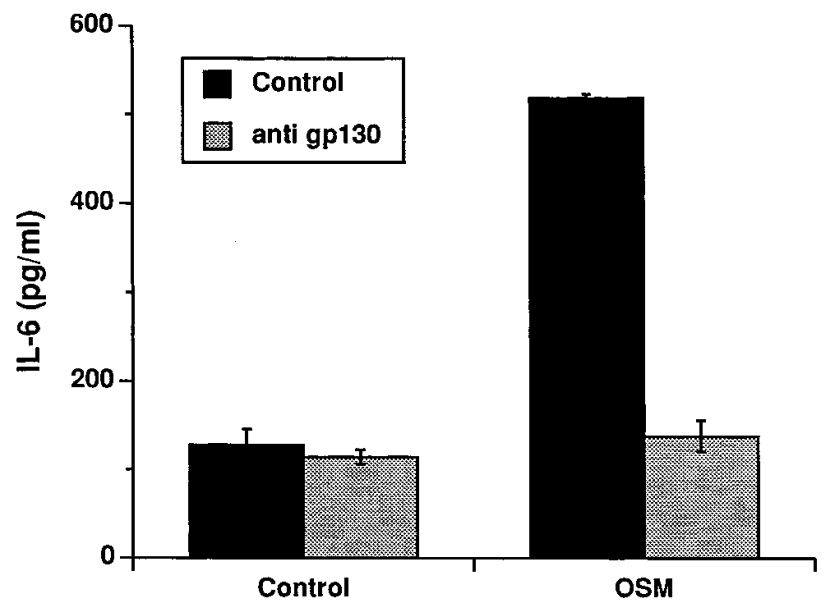

Figure 9. Antibodies against gp130 block the activation of endothelial cells by oncostatin M. Endothelial cells were preincubated with buffer alone or $50 \mu \mathrm{g} / \mathrm{ml}$ anti-gp130 for $90 \mathrm{~min}$ and then incubated in the presence of the antibody with buffer alone or $45 \mathrm{nM}$ oncostatin $\mathrm{M}$ for $4 \mathrm{~h}$. (A) Cell lysates were prepared and immunoblotted for E-selectin with mAb BBA-8, or $(B){ }^{111}$ In-PMN adhesion was determined as before. $(C)$ Supernatants were collected and assayed for IL- 6 by ELISA from endothelial cells treated similarly, except that the oncostatin $\mathrm{M}$ concentration was $45 \mathrm{pM}$. The data shown are representative of two experiments $(A$ and $B)$, and three experiments $(C)$.

low affinity receptor also mediated transcription of cytokines that the high affinity receptor could not, so it is clear that the low affinity receptor acts independently of the high affinity response.

Events induced by both classes of receptors may be relevant in vivo. Circulating levels of oncostatin $M$ are normally undetectable, but rise in septic patients over 100 -fold to $45 \mathrm{pM}$ (19). We found even greater increases in circulating oncostatin $\mathrm{M}$ levels in plasma from patients diagnosed with the acute respiratory distress syndrome (our unpublished observations). These concentrations are sufficient to stimulate endothelial cells through their high affinity receptor, but would have little effect on events mediated by the low affinity receptor. However, the concentration of oncostatin $\mathrm{M}$ in focal lesions that contain activated $\mathrm{T}$ cells or macrophages could be much higher than circulating levels. For example, conditioned medium from HTLV-II infected T cells contains 20 to $45 \mathrm{nM}$ oncostatin M (15). Thus the local concentrations of macrophage-like cells

in aneurysmal tissue that stained heavily for oncostatin $\mathrm{M}$, or the localized production of oncostatin $\mathrm{M}$ in the lesions of AIDS-associated Kaposi's sarcoma $(7,39)$ may allow the low affinity oncostatin $\mathrm{M}$ receptor to participate in endothelial cell activation.

A distinct difference between endothelial cell activation by oncostatin $\mathrm{M}$ and other inflammatory cytokines is the stimulation of PMN transmigration through monolayers in the absence of IL-8 synthesis. IL-8 is thought to be a key component in the accumulation of PMNs in acute inflammation $(33,40)$. It is synthesized in parallel with E-selectin (31), and both the IL-6 and IL-8 promoters have essential NF- $\mathrm{BB}$ and NF-IL-6 sites that are necessary and sufficient for stimulated transcription (41-43). This would suggest that oncostatin M-stimulated endothelial cells should produce these cytokines in parallel, but IL-6 synthesis in the absence of detectable IL-8 synthesis shows other factors modulate the function of this core region. Oncostatin $\mathrm{M}$ in vivo and in vitro induced leukocyte transmi- 
gration, so we searched for a leukocyte agonist other than IL-8. We found that oncostatin $\mathrm{M}$ induced the synthesis of GRO $\beta$ and ENA-78 through a high affinity receptor, and GRO $\alpha$ through a low affinity receptor. Each of these cytokines stimulate leukocytes through the same IL- 8 B receptor, and so could account for the transmigration we observed. This is the first instance where IL-8 can clearly be discounted as the transcriptionally-regulated chemoattractant responsible for leukocyte trafficking. For the first time, we demonstrate that high and low affinity oncostatin $M$ receptors have different and separable functions. The large number of receptors for oncostatin $\mathrm{M}$ on endothelial cells gives oncostatin $\mathbf{M}$ unique capabilities compared to its family members, while the separate signals initiated by its two classes of receptors distinguishes oncostatin $\mathrm{M}$ from the proinflammatory response to other inflammatory cytokines.

\section{Acknowledgments}

We thank Dr. Kurt Albertine (University of Utah, Salt Lake City, UT) for help with immunohistochemistry; Tada-atsu Imaizumi for performing ENA-78 ELISA; Rodger McEver and Kamala Patel (University of Oklahoma, Oklahoma City, OK) for P6E2 anti-E-selectin, G1 and S1 anti-P-selectin monoclonal antibodies; and Michael Gallatin (ICOS Corp., Seattle, WA) for anti-ICAM-1 monoclonal antibody. We would also like to thank Donelle Benson, Deborah Pinkowski, Ruth Ann Green, Margaret Vogel, and Wenhua Li for leukocyte isolation and endothelial cell culture. We are grateful to Aaron Ponstler for aid with immunoblotting.

This work was supported by the National Institutes of Health grant NIH HL50513, HL44525, and the Nora Eccles Treadwell Foundation.

\section{References}

1. Rose, T.M., and A.G. Bruce. 1991. Oncostatin M is a member of a cytokine family that includes leukemia-inhibitory factor, granulocyte colony-stimulating factor, and interleukin 6. Proc. Natl. Acad. Sci. USA. 88:8641-8645.

2. Bruce, A.G., T.M. Rose, P.S. Linsley, and P.M. Wallace. 1996. Oncostatin M. In Human Cytokines, Handbook for Basic and Clinical Research Volume II. B.B. Aggarwal and J.U. Gutterman, editors. Blackwell Science, Inc., Cambridge. 361-383.

3. Liu, J., B. Modrell, A. Aruffo, J.S. Marken, T. Taga, K. Yasukawa, M. Murakami, T. Kishimoto, and M. Shoyab. 1992. Interleukin-6 signal transducer gp130 mediates oncostatin M signaling. J. Biol. Chem. 267:16763-16766.

4. Thoma, B., T.A. Bird, D.J. Friend, D.P. Gearing, and S.K. Dower. 1994. Oncostatin $\mathrm{M}$ and leukemia inhibitory factor trigger overlapping and different signals through partially shared receptor complexes. J. Biol. Chem. 269:62156222 .

5. Gearing, D.P., S.F. Ziegler, M.R. Comeau, D. Friend, B. Thoma, D. Cosman, L. Park, and B. Mosley. 1994. Proliferative responses and binding properties of hematopoietic cells transfected with low-affinity receptors for leukemia inhibitory factor, oncostatin M, and ciliary neurotrophic factor. Proc. Natl. Acad. Sci. USA. 91:1119-1123.

6. Malik, N., J.C. Kallestad, N.L. Gunderson, S.D. Austin, M.G. Neubauer, V. Ochs, H. Marquardt, J.M. Zarling, M. Shoyab, C.-M. Wei, et al. 1989. Molecular cloning, sequence analysis, and functional expression of a novel growth regulator, Oncostatin M. Mol. Cell. Biol. 9:2847-2853.

7. Cai, J., P.S. Gill, R. Masood, P. Chandrasoma, B. Jung, R.E. Law, and S.F. Radka. 1994. Oncostatin-M is an autocrine growth factor in Kaposi's sarcoma. Am. J. Pathol. 145:74-79.

8. Grove, R.I., C. Eberhardt, S. Abid, C. Mazzucco, J. Liu, P. Kiener, G. Todaro, and M. Shoyab. 1993. Oncostatin M is a mitogen for rabbit vascular smooth muscle cells. Proc. Natl. Acad. Sci. USA. 90:823-827.

9. Brown, T.J., J.M. Rowe, L. Jingwen, and S. Mohammed. 1991. Regulation of IL-6 expression by oncostatin M. J. Immunol. 147:2175-2180.

10. Linsley, P.S., M. Bolton-Hanson, D. Horn, N. Malik, J.C. Kallestad, V. Ochs, J.M. Zarling, and M. Shoyab. 1989. Identification and characterization of cellular receptors for the growth regulator, Oncostatin M. J. Biol. Chem. 264: $4282-4289$.

11. Amaral, M.C., S. Miles, G. Kumar, and A.E. Nel. 1993. Oncostatin-M stimulates tyrosine protein phosphorylation in parallel with the activation of p42MAPK/ERK-2 in Kaposi's cells. J. Clin. Invest. 92:848-857.

12. Yao, L., J. Pan, H. Setiadi, K.D. Patel, and R.P. McEver. 1996. Interleukin 4 or oncostatin $\mathrm{M}$ induces a prolonged increase in P-selectin mRNA and protein in human endothelial cells. J. Exp. Med. 184:81-92.

13. Miles, S.A., O. Martinez-Maza, A. Rezai, L. Magpantay, T. Kishimoto, S. Nakamura, S.F. Radka, and P.S. Linsley. 1992. Oncostatin M as a potent mitogen for AIDS-Kaposi's sarcoma-derived cells. Science (Wash. DC). 255:14321434.

14. Ruszczak, Z., A.M. Da Silva, and C.E. Orfanos. 1987. Kaposi's sarcoma in AIDS. Am. J. Dermatopathology. 9:388-398.

15. Fiorelli, V., R. Gendelman, F. Samaniego, P.D. Markham, and B. Ensoli. 1995. Cytokines from activated T cells induce normal endothelial cells to acquire the phenotypic and functional features of AIDS-Kaposi's sarcoma spindle cells. J. Clin. Invest. 95:1723-1734.

16. Malik, N., H.S. Haugen, B. Modrell, M. Shoyab, and C.H. Clegg. 1995. Developmental abnormalities in mice transgenic for bovine oncostatin M. Mol. Cell. Biol. 15:2349-2358.

17. Clegg, C.H., J.T. Rulffes, P.M. Wallace, and H.S. Haugen. 1996. Regulation of an extrathymic T-cell development pathway by oncostatin M. Nature (Lond.). 384:261-263.

18. Wallace, P.M., J.F. Macmaster, J.R. Rillema, K.A. Rouleau, M.B. Hanson, S.A. Burstein, and M. Shoyab. 1996. In vivo properties of oncostatin M. Ann. NY. Acad. Sci. 42-54.

19. Guillet, C., M. Fourcin, S. Chevalier, A. Pouplard, and H. Gascan. 1995. ELISA detection of circulating levels of LIF, OSM, and CNTF in septic shock. Ann. NY. Acad. Sci. 762:407-412.

20. Zimmerman, G.A., T.M. McIntyre, and S.M. Prescott. 1985. Thrombin stimulates the adherence of neutrophils to human endothelial cells in vitro. $J$. Clin. Invest. 76:2235-2246.

21. Zimmerman, G.A., T.M. McIntyre, M. Mehra, and S.M. Prescott. 1990 Endothelial cell-associated platelet-activating factor: a novel mechanism for signaling intercellular adhesion. J. Cell. Biol. 110:529-540.

22. Patel, K.D., V. Modur, G.A. Zimmerman, S.M. Prescott, and T.M. McIntyre. 1994. The necrotic venom of the brown recluse spider induces dysregulated endothelial cell-dependent neutrophil activation. Differential induction of GM-CSF, IL-8, and E-selectin expression. J. Clin. Invest. 94:631-642.

23. Modur, V., G.A. Zimmerman, S.M. Prescott, and T.M. McIntyre. 1996. Endothelial cell inflammatory responses to TNF $\alpha$ : ceramide-dependent and -independent mitogen-activated protein kinase cascades. J. Biol. Chem. 271: 13094-13102.

24. Laemmli, U.K. 1970. Cleavage of structural proteins during the assembly of the head of bacteriophage T4. Nature (Lond.). 227:680-685.

25. Funk, C.D., and G.A. FitzGerald. 1991. Eicosanoid forming enzyme mRNA in human tissues: analysis by quantitative polymerase chain reaction. $J$. Biol. Chem. 266:12508-12513.

26. Haskill, S., A. Peace, J. Morris, S.A. Sporn, A. Anisowicz, S.W. Lee, T. Smith, P. Ralph, and R. Sager. 1990. Identification of three related human GRO genes encoding cytokine functions. Proc. Natl. Acad. Sci. USA. 87:77327736.

27. MacSweeney, S.T., J.T. Powell, and R.M. Greenhalgh. 1994. Pathogenesis of abdominal aortic aneurysm. Br. J. Surg. 81:935-941.

28. Ramshaw, A.L., D.E. Roskell, and D.V. Parums. 1994. Cytokine gene expression in aortic adventitial inflammation associated with advanced atherosclerosis (chronic periaortitis). J. Clin. Pathol. 47:721-727.

29. Newman, K.M., J. Jean-Claude, H. Li, W.G. Ramey, and M.D. Tilson. 1994. Cytokines that activate proteolysis are increased in abdominal aortic aneurysms. Circulation. 90:11224-11227.

30. Lorant, D.E., K.D. Patel, T.M. McIntyre, R.P. McEver, S.M. Prescott and G.A. Zimmerman. 1991. Coexpression of GMP-140 and PAF by endothelium stimulated by histamine or thrombin: a juxtacrine system for adhesion and activation of neutrophils. J. Cell Biol. 115:223-234.

31. Pober, J.S., and R.S. Cotran. 1995. Cytokines and endothelial cell biology. Physiol. Rev. 70:427-451.

32. Zimmerman, G.A., T.M. McIntyre, and S.M. Prescott. 1996. Adhesion and signaling in vascular cell-cell interactions. J. Clin. Invest. 98:1699-1702.

33. Huber, A.R., S.L. Kunkel, R.F. Todd III, and S.J. Weiss. 1991. Regulation of transendothelial neutrophil migration by endogenous interleukin-8. Science (Wash. DC). 254:99-102.

34. Imaizumi, T., K.H. Albertine, D.L. Jicha, T.M. McIntyre, S.M. Prescott and G.A. Zimmerman. 1997. Human endothelial cells synthesize ENA-78: Relationship to IL-8 and to signaling of PMN adhesion. Am. J. Respir. Cell Mol. Biol. (In press).

35. Sako, D., X-J. Chang, K.M. Barone, G. Vachino, H.M. White, G. Shaw, G.M. Veldman, K.M. Bean, T.J. Ahern, B. Furie, et al. 1993. Expression cloning of a functional glycoprotein ligand for P-selectin. Cell. 75:1179-1186.

36. Moore, K.L., K.D. Patel, R.E. Bruehl, L. Fugang, D.A. Johnson, H.S. Lichenstein, R.D. Cummings, D.F. Bainton, and R.P. McEver. 1995. P-selectin glycoprotein ligand-1 mediates rolling of human neutrophils on P-selectin. $J$. Cell Biol. 128:661-671.

37. Shankar, R., C.A. de la Motte, E.J. Poptic, and P.E. DiCorleto. 1994. Thrombin receptor-activating peptides differentially stimulate platelet-derived 
growth factor production, monocytic cell adhesion, and E-selectin expression in human umbilical vein endothelial cells. J. Biol. Chem. 269:13936-13941.

38. Sugama, Y., C. Tiruppathi, K. Offakidevi, T.T. Andersen, J.W. Fenton, and A.B. Malik. 1992. Thrombin-induced expression of endothelial P-selectin and intercellular adhesion molecule-1: a mechanism for stabilizing neutrophil adhesion. J. Cell Biol. 119:935-944.

39. Nair, B.F., A.L. Devico, S. Nakamura, D. Copeland, Y. Chen, A. Patel, and T. O'Neil. 1992. Identification of a major growth factor for AIDS-Kaposi's sarcoma cells as Oncostatin M. Science (Wash. DC). 255:1430-1432.

40. Sekido, N., N. Mukalda, A. Harada, I. Nakanishi, Y. Watanabe, and K. Matsushima. 1993. Prevention of lung reperfusion injury in rabbits by a monoclonal antibody against interleukin-8. Nature (Lond.). 365:654-657.
41. Matsusaka, T., K. Fujikawa, Y. Nishio, N. Mukaida, K. Matsushima, T. Kishimoto, and S. Akira. 1993. Transcription factors NF-IL6 and NF-кB synergistically activate transcription of the inflammatory cytokines, interleukin 6 and interleukin 8. Proc. Natl. Acad. Sci. USA. 90:10193-10197.

42. Kunsch, C., R.K. Lang, C.A. Rosen, and M.F. Shannon. 1994. Synergistic transcriptional activation of the IL-8 gene by NF-кB p65 (RelA) and NF-IL-6. J. Immunol. 153:153-164.

43. Mukaida, N., Y. Mahe, and K. Matsushima. 1990. Cooperative interaction of nuclear factor-кB-and cis-regulatory enhancer binding protein-like factor binding elements in activating the interleukin- 8 gene by pro-inflammatory cytokines. J. Biol. Chem. 265:21128-21133. 